\title{
Bettina Saier \\ Age-dependent zonation of the periwinkle Littorina littorea (L.) in the Wadden Sea
}

Received: 24 May 2000 / Received in revised form: 25 September 2000 / Accepted: 26 September 2000 / Published online: 16 November 2000 C) Springer-Verlag and AWI 2000

\begin{abstract}
On sedimentary tidal flats near the island of Sylt (German Bight, North Sea) abundance and size distribution of periwinkles, Littorina littorea L., were studied in low intertidal and in shallow and deep subtidal mussel beds (Mytilus edulis L.). In low intertidal mussel beds, surveys revealed that high densities $\left(1,369 \pm 571 \mathrm{~m}^{-2}\right)$ of juvenile snails $(\leq 13 \mathrm{~mm})$ were positively correlated with strong barnacle epigrowth (Semibalanus balanoides L. and Balanus crenatus Bruguière) on mussels. A subsequent field experiment showed that recruitment of $L$. littorea was restricted to the intertidal zone. Abundances of periwinkles $\left(213 \pm 114 \mathrm{~m}^{-2}\right)$ and barnacles abruptly decreased in the adjacent shallow subtidal zone, which served as a habitat for older snails (>13 mm). L. littorea was completely absent from disjunct deep $(5 \mathrm{~m})$ subtidal mussel beds. Snail abundance varied seasonally with maxima of $>4,000 \mathrm{~m}^{-2}$ in low intertidal mussel beds in October and minima in July, just before the onset of new recruitment. I suggest that the presence of cracks and crevices among the dense barnacle overgrowth in intertidal mussel beds favoured recruitment and survival of juvenile snails. Larger (older) specimens are assumed to actively migrate to the less favourable adjacent subtidal. Therefore, intertidal mussel beds are considered as nurseries for the population of L. littorea in the Wadden Sea.
\end{abstract}

Keywords Littorina littorea $\cdot$ Intertidal $\cdot$ Subtidal . Mussel bed · Barnacles

\section{Introduction}

The zonation patterns of intertidal gastropods have been extensively studied in rocky shore communities, whilst

Communicated by H.-D. Franke

B. Saier $(\square)$

Alfred-Wegener-Institute for Polar and Marine Research,

Wadden Sea Station Sylt, Hafenstrasse 43,

25992 List, Germany

e-mail: bsaier@awi-bremerhaven.de

Tel.: +49-4651-956135, Fax: +49-4651-956200 variations in mean size of intertidal snails with shore level have also been widely reported (e.g. Williams 1964; Edwards 1969; Vermeij 1972; Underwood 1973, 1979; Chapman 1994; Williams 1995). Among Littorinidae, the largest individuals often occur towards the species' upper distributional limits and the smallest towards the lower distributional limits, but there are many exceptions to this (Vermeij 1972). The periwinkle Littorina littorea (L.), in particular, exhibits highly variable patterns with complex size gradients (Smith and Newell 1955; Williams 1964; Vermeij 1972). Furthermore L. littorea is the only littorinid species which is commonly found on both hard substrates and in soft bottom environments (Bandel 1974). On the muddy and sandy tidal flats of the Wadden Sea, for example, L. littorea represents the most common herbivorous grazer. The distribution of the population is highly patchy due to the periwinkle's reliance on solid substrates such as stones, boulders, macrophytes [Fucus vesiculosus forma mytili (Nienburg), Zostera spp.] or mussel shells (Mytilus edulis L.). Densities of up to $2,000 \mathrm{~m}^{-2}$ were reported from intertidal mussel beds (Albrecht and Reise 1994) and Fenske (1997) supposed that the available resources on the mussel beds were sufficient to maintain a high population density of L. littorea and rejected the possibility of intraspecific competition. The snails feed on the microalgal films (diatoms) covering the mussel shell surfaces including young sporelings of ephemeral algae or young stages of barnacles, and thus play an important role in structuring the mussel bed community (Wilhelmsen and Reise 1994; Albrecht 1998). Near the island of Sylt these mussel beds gradually extend from mid-intertidal to adjacent shallow subtidal zones and, therefore, present an excellent site for studying zonation patterns of $L$. littorea in the Wadden Sea. Moreover, these mussel beds are commonly overgrown by barnacles (Albrecht 1998) among which Semibalanus balanoides L. dominates the intertidal zone while Balanus crenatus Bruguière is primarily found at subtidal sites (Albrecht and Reise 1994; Buhs and Reise 1997). In between the cracks and crevices of this barnacle cover, small specimens of $L$. littorea may 
find suitable microhabitats that could provide refuges from crab predation as suggested by Choat (1977). Scherer and Reise (1981) found that shore crabs, Carcinus maenas L., preferentially prey on small snails between 6 and $10 \mathrm{~mm}$ shell height. Furthermore, crabs increase in both density and size with increasing depth (B. Scherer, unpublished report). A decrease in abundance of small L. littorea is consequently expected towards the subtidal zone which may still be favourable for older (larger) snails. Also, balanid epigrowth on mussels was expected to favour the survival of small snails while the same barnacle cover might hamper the crawling and grazing activity of larger and older individuals (Albrecht 1998; Buschbaum and Reise 1999).

Therefore, the first step in this study was to establish the vertical distribution of the different size classes of $L$. littorea in low intertidal and in shallow and deep subtidal mussel beds and concurrently measure barnacle epigrowth. I checked for seasonal changes in this distribution and, subsequently, a field experiment tested the hypothesis that recruitment of L. littorea was restricted to the intertidal zone.

\section{Methods}

Study area

The fieldwork was done at mussel beds in Königshafen, a shallow intertidal bay at the northern tip of the island of Sylt in the eastern North Sea (Fig. 1). Average salinity is 30 psu and mean water temperature is $15^{\circ} \mathrm{C}$ in summer and $4^{\circ} \mathrm{C}$ in winter. Tides are semi-diurnal with an amplitude of $1.8 \mathrm{~m}$. Spring and neap tides differ by less than $0.2 \mathrm{~m}$, but strong easterly winds may decrease the low tide level by $1 \mathrm{~m}$, while westerly gales may raise the high tide level by $>2 \mathrm{~m}$ (Reise 1985). The intertidal zone comprises an area of about $4.5 \mathrm{~km}^{2}$ and is characterised by extensive sandy and muddy flats (about 84\%). Seagrass beds (Zostera marina L. and Zostera noltii Hornem.) occur in the mid-tidal zone and cover another $12 \%$ of the area. Intertidal mussel beds account for only $1 \%$ (Reise et al. 1994). A detailed description of the hydrography, geology, sediments and biota of the study area is given by Reise (1985), G. Austen (1994), I. Austen (1994), Bayerl and Higelke (1994) and Reise et al. (1994).

The investigated beds of $M$. edulis are all located near the low water tide mark (Fig. 1) and represent intertidal and shallow subtidal habitats within about $100 \mathrm{~m}$ of horizontal distance. In this study shallow subtidal habitats are referred to as areas remaining submerged at spring water low tides and comprise depths of about $0.5-1 \mathrm{~m}$ at mean low tide. Mean exposure time of low intertidal mussel beds was about $1 \mathrm{~h}$ per tide. Deep (>5 m) subtidal mussel beds occurred scarcely near Königshafen in 1997 and 1998; therefore, sampling of the deep mussel bed was carried out in a tidal channel Vortrapptief in the south of Sylt (Fig. 1; $54^{\circ} 41.85^{\prime} \mathrm{N}$; $\left.8^{\circ} 16.80^{\prime} \mathrm{E}\right)$.

\section{Abundance and size of $L$. littorea and barnacle epigrowth}

To obtain abundances of L. littorea and quantify barnacle epigrowth, sampling was performed in low intertidal and adjacent shallow subtidal mussel beds using a stratified random sampling design. A total of 18 samples per tidal level was taken (six replicates in both intertidal and the adjacent subtidal zones of each of the three sites) once a year in August/September 1997 and 1998 using a box corer of $1,000 \mathrm{~cm}^{2}$. Intertidal samples were taken during tidal emergence, and subtidal samples by diving. In addition,

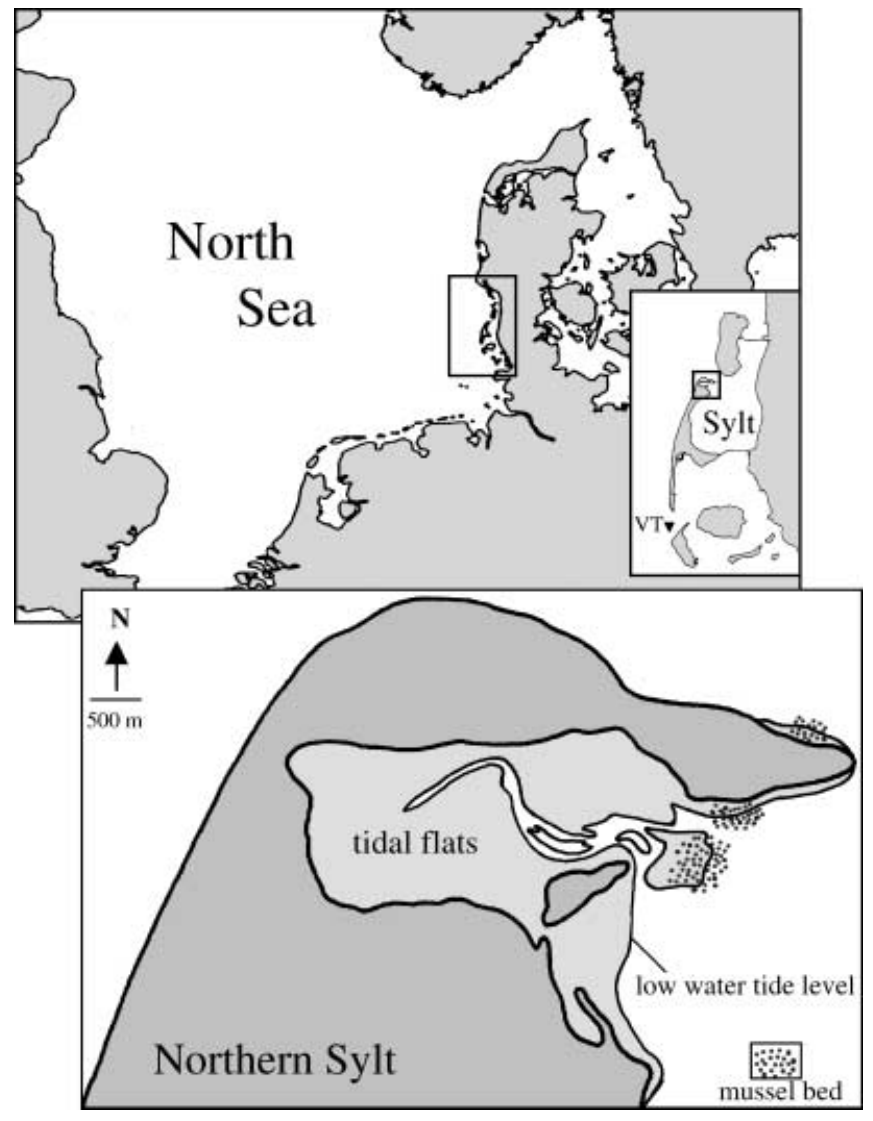

Fig. 1 Investigation area in the Wadden Sea near the island of Sylt, North Sea, Germany. Above Overview of North Sea and location of the island of Sylt and the southern sampling site at the Vortrapptief $(V T)$. Below Tidal flats of northern Sylt with distribution of investigated mussel beds (dotted) near the low water tide mark between 1997 and 1999

ten samples of $500 \mathrm{~cm}^{2}$ were collected from a $5 \mathrm{~m}$ deep subtidal mussel bed in the south of Sylt in August 1997 by means of a Van Veen grab. The contents were washed through $1 \mathrm{~mm}$ meshes to collect and count all periwinkles and mussels, except the smallest recruits. Barnacle epigrowth of $S$. balanoides and $B$. crenatus on M. edulis was quantified by estimating the barnacle cover of each mussel shell surface to the nearest $25 \%$ (up to $25 \%=$ no or few barnacles; up to $50 \%=$ half cover; up to $75 \%=$ three-quarters cover; $100 \%=$ total cover). Balanids mostly had a shell diameter of around $5 \mathrm{~mm}$ and only $M$. edulis specimens with shell length $>35 \mathrm{~mm}$ were considered, as balanids generally occurred from this size upward.

The seasonal distribution of L. littorea was studied by taking six replicates of $1,000 \mathrm{~cm}^{2}$ each in the low intertidal and adjacent shallow subtidal zone of one mussel bed from September 1997 to October 1999 (September and October 1997; April, July, September and October 1998; July and October 1999) as described above. To obtain information on size distributions of L. littorea, six replicate samples of $1,000 \mathrm{~cm}^{2}$ each were taken in July 1999 in the low intertidal and adjacent shallow subtidal zone of that mussel bed and treated as before. Additionally, shell heights were measured from base to apex to the nearest $1 \mathrm{~mm}$ using Vernier callipers. Snails $\leq 13 \mathrm{~mm}$ were regarded as juveniles and snails $>13 \mathrm{~mm}$ as sexually mature adults (Dethlefs, unpublished report).

Throughout the investigation period, qualitative records on the occurrence of $L$. littorea in the deep ( $\geq 5 \mathrm{~m}$ ) subtidal zone of northern Sylt were taken by scuba diving. 
Recruitment of $L$. littorea

To test the hypothesis that recruitment of L. littorea was restricted to the intertidal zone, a field experiment was performed during larval settlement in the summer of 1999. Cylindrical cages $20 \mathrm{~cm}$ in diameter and height were constructed from plastic wire $(4 \mathrm{~mm}$ mesh size) and anchored in the low intertidal and adjacent shallow subtidal zone of one mussel bed from 25 June to 5 August. In each zone six closed cages were used to exclude predators. To find out whether crab predation affects post-settlement survival, six open cages offering predators access were installed. Approximately 6 weeks later, when recruits had grown to a shell height $>500 \mu \mathrm{m}$, the whole cage content of $314 \mathrm{~cm}^{2}$ was sieved through $500 \mu \mathrm{m}$ meshes and L. littorea $\leq 2 \mathrm{~mm}$ shell height were sorted and counted.

\section{Statistical analysis}

Results are presented as arithmetic means with standard deviation (MathType!ZZhx47!eeaaduGcbiZG4zqeaaaa!015C! \pm SD). They were analysed by means of nonparametric Kruskal-Wallis $H$-tests. Since data were not normally distributed and mean values and variances turned out to be correlated, an analyses of variance (ANOVA) was not applied. For pairwise comparisons the MannWhitney $U$-test was used. Effects were considered to be statistically significant if $P$ was $<0.05$ and the Bonferroni procedure was applied for multiple comparisons of data.

\section{Results}

Abundance and vertical distribution of $L$. littorea

In 1997 and 1998 abundances of L. littorea significantly differed between low intertidal, shallow subtidal and deep subtidal mussel beds (Kruskal-Wallis test, $P<0.0001$ ) (Fig. 2a). The highest abundances with mean densities of $1,369 \pm 571 \mathrm{~m}^{-2}$ (pooled data for both years) were found intertidally. These were significantly higher in 1998 $\left(1,588 \pm 541 \mathrm{~m}^{-2}\right)$ than in $1997\left(1,151 \pm 526 \mathrm{~m}^{-2}\right)$ (pairwise Mann-Whitney $U$-test, $P<0.05)$. Snail abundances significantly decreased in adjacent shallow subtidal mussel beds to $213 \pm 114 \mathrm{~m}^{-2}$ (pooled data for both years). No significant between-year differences were found in the adjacent subtidal zone (pairwise Mann-Whitney $U$-test, $P=0.27)$ between $1997\left(198 \pm 118 \mathrm{~m}^{-2}\right)$ and 1998 $\left(228 \pm 112 \mathrm{~m}^{-2}\right)$. In the deep subtidal mussel bed, L. littorea abundance significantly dropped to zero (pairwise Mann-Whitney $U$-test; $P<0.0001$ ). No snails were found in qualitative investigations of the deep subtidal zone in 1997 and 1998.

\section{Extent of barnacle overgrowth on mussel shells}

Barnacle epigrowth by $S$. balanoides and B. crenatus decreased with increasing submergence time (Fig. 2b, pooled data of 1997 and 1998). It was strongest in low intertidal mussel beds where $58 \%$ of the mussels had no or few barnacles, $29 \%$ were covered half, $8 \%$ reached up to three-quarters cover and $5 \%$ of mussel shells were totally covered. In adjacent shallow subtidal mussel beds barnacle cover was intermediate; $82 \%$ of the mussels

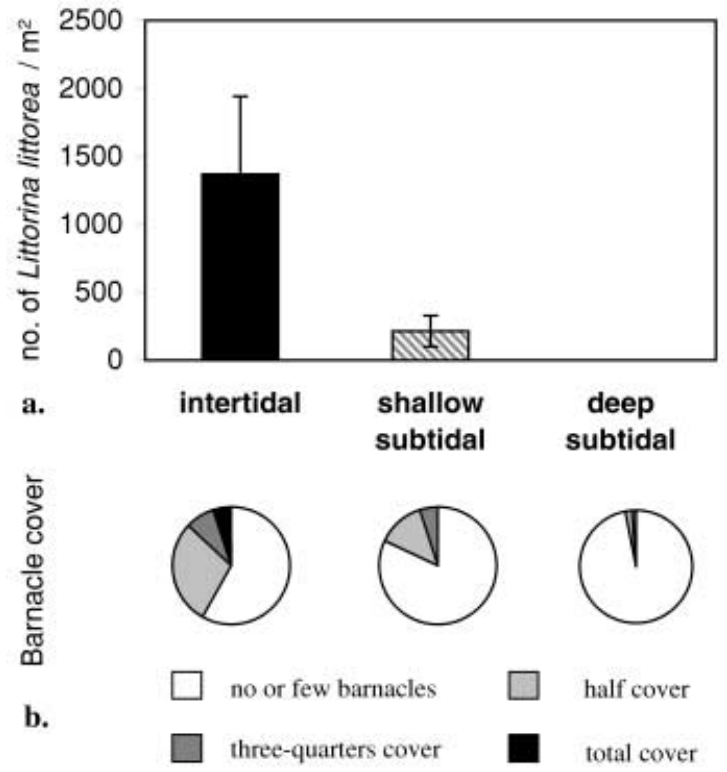

Fig. 2 a Tidal zonation of Littorina littorea abundances (means of $n$ samples $\pm \mathrm{SD} ; n=18$ for intertidal and shallow subtidal; $n=10$ for deep subtidal) and $\mathbf{b}$ barnacle (Semibalanus balanoides and Balanus crenatus) percentage cover on Mytilus edulis in intertidal, shallow and deep subtidal mussel beds in August/September 1997 and 1998; L. littorea was completely absent from deep subtidal mussel beds

were overgrown by no or few barnacles and $12 \%$ were half covered or more. Barnacle cover was lowest in the deep subtidal, where $97 \%$ of the mussels were clean or had few barnacles and 3\% were half covered or more. A comparison between 1997 and 1998 revealed that barnacle overgrowth in the intertidal zone was higher in 1998 (46\% of mussels had no or few barnacles in 1998 compared with $57 \%$ in 1997) while in the subtidal zone it was higher in 1997 (83\% of mussels had no or few barnacles in 1998 compared with 51\% in 1997).

\section{Seasonal variability in the abundance of L. littorea}

In the course of 1997-1999 intertidal snail abundances varied seasonally. The lowest abundances occurred in early summer (July) followed by an increase due to recruitment of $L$. littorea, until in October snail abundances rose within a month to extremely high densities of up to $4,367( \pm 2,441), 4,215( \pm 1,690)$ and 3,883 $( \pm 1,026)$ individuals $\mathrm{m}^{-2}$ in 1997,1998 and 1999 , respectively (Fig. 3). These autumnal peaks were due to juvenile snails up to 1 year old ( $\leq 13 \mathrm{~mm}$ shell height). In 1997, abundances remained fairly high during winter and decreased to $3,700( \pm 705)$ individuals $\mathrm{m}^{-2}$ by April 1998. Numbers decreased to lowest abundances in early summer (July) just before the new (0-) year class appeared in the samples. No distinct seasonality was observed in the subtidal zone, i.e. adult snail densities were similar in the course of 1997-1999 and only significant- 


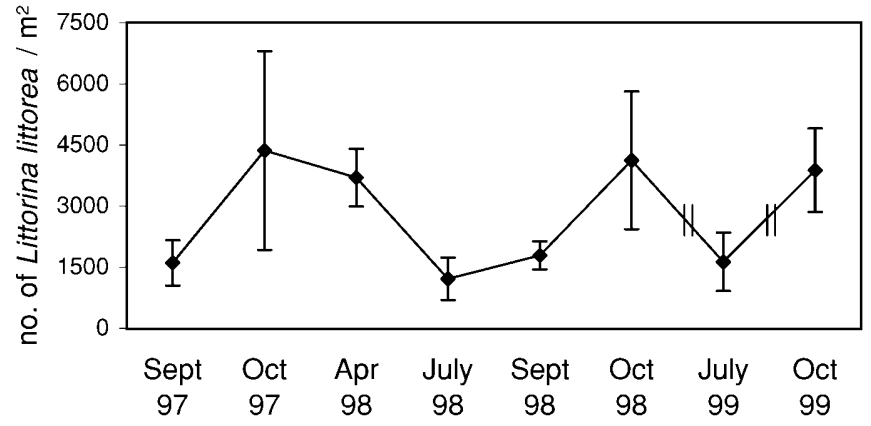

Fig. 3 Seasonal variability of Littorina littorea abundances in the intertidal zone of a mussel bed in the course of 3 years (means of six replicates $\pm \mathrm{SD}$ )

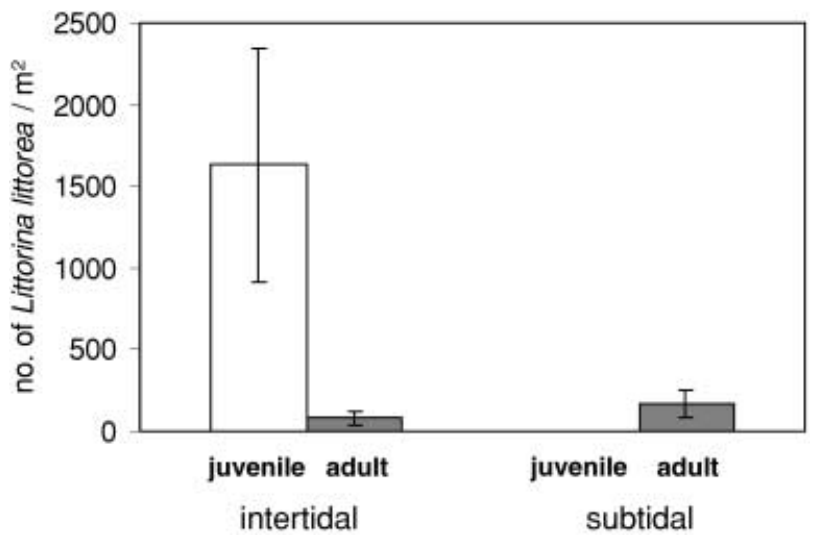

Fig. 4 Abundances of juvenile ( $\leq 13 \mathrm{~mm}$ shell height) and adult (>13 mm shell height) Littorina littorea in the intertidal and shallow subtidal zone of a mussel bed in July 1999 (means of six replicates \pm SD)

ly higher in October $1997\left(583 \pm 343 \mathrm{~m}^{-2}\right)$ (KruskalWallis test, $P<0.05$ ).

Size distribution and recruitment of L. littorea

L. littorea abundances consisted of more than $75 \%$ of juveniles ( $\leq 13 \mathrm{~mm}$ shell height) at all intertidal sites during the investigation period. In July 1999 these comprised $95 \%$ of the littorinid snails, whereas the adjacent shallow subtidal zone of the mussel bed was exclusively inhabited by adult (>13 mm shell height) snails (Fig. 4). The field experiment demonstrated that recruitment of $L$. littorea was restricted to the intertidal zone: $509( \pm 143)$ $\mathrm{m}^{-2} \mathrm{~L}$. littorea recruits ( $\leq 2 \mathrm{~mm}$ shell height) were found in open cages $\left(314 \mathrm{~cm}^{2}\right)$ that offered free access to predators. A similar abundance was found in closed predator exclusion cages $\left(487 \pm 89 \mathrm{~m}^{-2}\right)$ indicating that predation did not affect the survival of early life stages of $L$. littorea. However, in the shallow subtidal zone of that mussel bed no recruits were found in both open and closed cages.

\section{Discussion}

In this investigation L. littorea attained an abundance of some thousands of individuals per $\mathrm{m}^{2}$ in low intertidal mussel beds, and similar densities from that area were recorded by Albrecht and Reise (1994). Within a few metres of horizontal distance, snail densities abruptly decreased in the adjacent shallow subtidal and dropped to zero in the deep subtidal zone. Few studies have been published on the subtidal zone of the Wadden Sea but all described L. littorea as extremely rare or absent (Hagmeier and Kändler 1927; Riesen and Reise 1982; Dekker 1989; Buhs and Reise 1997). However, periwinkles may live subtidally on other coasts (Moore 1937; Bandel 1974; Gendron 1977; Hylleberg and Tang Christensen 1978; Fretter and Graham 1980; Gilkinson and Methven 1991) and in the Baltic Sea a population of L. littorea closely related to that in the Wadden Sea (Wilhelmsen 1998) even lives submerged throughout its life (Lauckner 1984a; Wahl and Sönnichsen 1992). Therefore, the predominantly intertidal occurrence in the Wadden Sea cannot be explained by physiological intolerance to submergence. Instead, the absence of L. littorea in the deep subtidal zone in the Wadden Sea seems primarily to be a consequence of restricted recruitment to the intertidal. The field experiment revealed that very small $(\leq 2 \mathrm{~mm})$ snails were limited to low intertidal mussel beds and that these were not significantly reduced in density by predators (Carcinus maenas L.). Most accounts describe settlement and recruitment of $L$. littorea as intertidal, especially in cracks, amongst barnacles and in their empty shells (Williams 1964; Gendron 1977; Little and Williams 1989). Intertidal mussel beds of the study site were heavily overgrown by barnacles, $S$. balanoides and B. crenatus, throughout the investigation period of 1997 and 1998. In between the cracks and crevices juvenile $(\leq 13 \mathrm{~mm})$ L. littorea predominantly co-occurred with the 0 -group and were observed foraging there. Barnacles have been shown to influence the population biology of a number of gastropods. Examples are limpets, Acmaea species (Choat 1977), Patella species (Lewis and Bowman 1975; Branch 1976) and the periwinkles L. neritoides L. (Lysaght 1953), L. sitkana Philippi (Jones and Boulding 1999) and L. littorea (Little and Williams 1989). This effect is usually attributed to the reduction in mortality of juveniles due to desiccation. Barnacles retain moisture during tidal emergence and also provide some shade and shelter from sunlight (Underwood 1979). In the Wadden Sea, however, juvenile periwinkles are able to survive much longer periods of exposure in more upshore seagrass beds (Linke 1939; Reise 1978) and may generally tolerate a wide range of harsh environmental conditions (Underwood 1979). Therefore, desiccation is assumed to be of minor importance for the survival of juveniles. Considering that in the low intertidal zone C. maenas increases in both density and size (B. Scherer, unpublished report) such barnacle interstices could well provide refuges from predation as suggested by Choat (1977). 
The prickly and irregular surface produced by barnacle cover might hamper the crawling activity of larger and older snails that could probably no longer feed within these areas (Albrecht 1998). Consequently, areas with low barnacle cover such as shell beds are preferentially inhabited by older and larger snails (personal observation). Probably, the same applies to subtidal zones where the feeding activity of juvenile seastars, Asterias rubens L., and C. maenas presumably decreased barnacle epigrowth on mussels. Thus, restricted intertidal recruitment and strong balanid overgrowth might lead to a distribution of juveniles $(\leq 13 \mathrm{~mm})$ inhabiting that part of the vertical range where juvenile mortality is low (Vermeij 1972) and where adults (>13 mm) encounter unfavourable conditions.

In the adjacent shallow subtidal zones of these mussel beds, higher densities of adult snails were found and juveniles were absent. This reflects a change of preferred habitat with age which is common in L. littorea on rocky shores. Smith and Newell (1955), for example, described a complex gradient with juvenile snails apparently living subtidally, adults inhabiting low and mid-intertidal levels, and second-year individuals occurring higher up in the tidal zone. On a rocky shore in Wales, juveniles were found to congregate near mean low water, whilst larger and older individuals occurred both above and below this level (Williams 1964).

Since this study demonstrated that recruitment of L. littorea was restricted to the intertidal, adults were either passively washed to lower levels or performed an active migration. Downward migrations were observed in many intertidal species of the Wadden Sea and may constitute an adaptation to escape from severe winter conditions on high tidal flats, e.g. the juvenile migration in lugworms, Arenicola marina L. (Reise 1985). This migratory behaviour was also reported from L. littorea in the Wadden Sea (K. Reise, personal communication) and other coasts (reviewed by Underwood 1979). Interestingly, Nicolaysen (unpublished report) described the emigration of juvenile first-year class of L. littorea $(\leq 13 \mathrm{~mm})$ from seagrass beds located more upshore to mussel clusters in the mid-intertidal region of the study site in July 1994. However, there is no further information about their final destiny. I assume that most of these migrating juveniles reached the low intertidal mussel beds some time later in October. By this time seasonal epibenthic predators (C. maenas) have usually already left the tidal flats to hibernate in subtidal regions. However, the presumed immigration of juvenile snails from seagrass beds in conjunction with a downward winter migration may just in part explain the peaks observed in the intertidal zone in this investigation during October 1997, 1998 and 1999. Additionally, tiny snails, perhaps overlooked earlier in the season, may account for those increases, as well as later settlement during the summer. Changes in habitat preference with size might also be a means of reducing intraspecific competition (Edwards 1969). However, Fenske (1997) was not able to detect intraspecific competition in L. littorea. In field experiments on mussel beds nearby, high densities of large individuals $(>17 \mathrm{~mm})$ did not lead to an emigration of small snails $(\leq 17 \mathrm{~mm})$. In conclusion, beds of $M$. edulis at low and mid-intertidal levels and seagrass beds higher up in the tidal zone harbour most of the juvenile population and are, therefore, important nurseries for L. littorea in the Wadden Sea, while mussel clusters might function as stepping stones between both habitats.

In the subtidal, larger snails may attain a size refuge and are thus relatively protected from predation by shore crabs while snails between 6 and $10 \mathrm{~mm}$ shell height were highly vulnerable and would suffer heavy mortality below the tide mark (Scherer and Reise 1981). Apart from that, the comparatively low subtidal abundances are likely to be a consequence of adult mortality caused by a heavy load of barnacle epibionts or increased parasitic infestation, as suggested by Buschbaum and Reise (1999) and Lauckner (1984b), respectively.

Similarly, on a New England rocky shore the distribution of L. littorea abruptly dropped to nearly zero in the subtidal zone, and Bertness (1984) assumed that the absence was due to heavy predation by Busycon canaliculatum. Whether predation by shore crabs contributes to the lack of L. littorea in the deep subtidal Wadden Sea seems likely but remains obscure. Further factors include the abundance or quality of available food which decreases towards the subtidal zone (Asmus, personal communication) and probably limits the distribution of their grazers such as L. littorea. Finally, while mussel beds near the low water tide mark gradually extend from intertidal to subtidal zones, deep subtidal mussel beds occur in some horizontal distance and thus might be inaccessible to intertidal recruits of $L$. littorea.

Acknowledgements I am grateful to Christian Buschbaum, Werner Armonies and Karsten Reise for discussions and thoughtful reviews of the manuscript. The experiments comply with the current laws. This article is in part based on a doctoral study in the Faculty of Biology, University of Hamburg.

\section{References}

Albrecht A (1998) Soft bottom versus hard rock: community ecology of macroalgae on intertidal mussel beds in the Wadden Sea. J Exp Mar Biol Ecol 229:85-109

Albrecht A, Reise K (1994) Effects of Fucus vesiculosus covering intertidal mussel beds in the Wadden Sea. Helgol Meeresunters 48:243-256

Austen G (1994) Hydrodynamics and particulate matter budget of Königshafen, southeastern North Sea. Helgol Meeresunters 48:183-200

Austen I (1994) The surficial sediments of Königshafen variations over the past 50 years. Helgol Meeresunters 48:163-171

Bandel K (1974) Studies on Littorinidae from the Atlantic. Veliger 17:92-114

Bayerl KA, Higelke B (1994) The development of northern Sylt during the latest Holocene. Helgol Meeresunters 48:145-162

Bertness MD (1984) Habitat and community modification by an introduced herbivorous snail. Ecology 65:370-381

Branch GM (1976) Interspecific competition experienced by South African Patella species. J Anim Ecol 45:507-529

Buhs F, Reise K (1997) Epibenthic fauna dredged from tidal channels in the Wadden Sea of Schleswig-Holstein: spatial patterns and a long-term decline. Helgol Meeresunters 51:343-359 
Buschbaum C, Reise K (1999) Effects of barnacle epibionts on the periwinkle Littorina littorea (L.). Helgol Meeresunters 53:5661

Chapman MG (1994) Small and broad-scale patterns of distribution of the upper-shore littorinid Nodilittorina pyramidalis in New South Wales. Aust J Ecol 19:83-95

Choat JH (1977) The influence of sessile organisms on the population biology of three species of acmaeid limpets. J Exp Mar Biol Ecol 26:1-26

Dekker R (1989) The macrozoobenthos of the subtidal western Dutch Wadden Sea. I. Biomass and species richness. Neth J Sea Res 23:57-68

Edwards DC (1969) Zonation by size as an adaptation for intertidal life in Olivella biplicata. Am Zool 9:399-417

Fenske C (1997) The importance of intraspecific competition in a Littorina littorea population in the Wadden Sea. Hydrobiologia 355:29-39

Fretter V, Graham A (1980) The prosobranch molluscs of Britain and Denmark: part 5, marine Littorinaceae. J Moll Stud [Suppl] 7:241-284

Gendron RP (1977) Habitat selection and migratory behaviour of the intertidal gastropod Littorina littorea (L.). J Anim Ecol 46:79-92

Gilkinson KD, Methven A (1991) Observations on the subtidal distributions of the intertidal rough periwinkle, Littorina saxatilis, and the common periwinkle, L. littorea, in a shallow embayment in Eastern Newfoundland. Can Field Nat 105: $522-525$

Hagmeier A, Kändler R (1927) Neue Untersuchungen im nordfriesischen Wattenmeer und auf den fiskalischen Austernbänken. Helgol Wiss Meeresunters 16:1-90

Hylleberg H, Tang Christensen J (1978) Factors affecting the intra-specific competition and size distribution of the periwinkle Littorina littorea (L.) Nat Jütl 20:193-202

Jones KMM, Boulding EG (1999) State-dependent habitat selection by an intertidal snail: the costs of selecting a physically stressful microhabitat. J Exp Mar Biol Ecol 242:149-177

Lauckner G (1984a) Brackish-water submergence of the common periwinkle, Littorina littorea, and its digenean parasites in the Baltic Sea and in the Kattegat. Helgol Meeresunters 37:177184

Lauckner G (1984b) Impact of trematode parasitism on the fauna of a North Sea tidal flat. Helgol Meeresunters 37:185-199

Lewis JR, Bowman S (1975) Local habitat-induced variations in the population dynamics of Patella vulgata L. J Exp Mar Biol Ecol 17:165-203
Linke O (1939) Die Biota des Jadebusens. Helgol Wiss Meeresunters 1:201-348

Little C, Williams GA (1989) Distribution of littorinid gastropods at Lough Hyne. Ir Nat J 23:48-53

Lysaght A (1953) Choice of habitat in Littorina neritoides. Br J Anim Behav 1:79-80

Moore HB (1937) The biology of Littorina littorea. Part I: growth of the shell and tissue, spawning, length of life and mortality. J Mar Biol Assoc UK 21:721-742

Reise K (1978) Experiments on epibenthic predation in the Wadden Sea. Helgol Wiss Meeresunters 31:55-101

Reise K (1985) Tidal flat ecology. Springer, Berlin Heidelberg New York

Reise K, Herre E, Sturm M (1994) Biomass and abundance of macrofauna in intertidal sediments of Königshafen in the northern Wadden Sea. Helgol Meeresunters 48:201-215

Riesen W, Reise K (1982) Macrobenthos of the subtidal Wadden Sea: revisited after 55 years. Helgol Meeresunters 35:409-423

Scherer B, Reise K (1981) Significant predation on micro- and macrobenthos by the crab Carcinus maenas L. in the Wadden Sea. Kiel Meeresforsch Sonderheft 5:490-500

Smith JE, Newell GE (1955) The dynamics of the zonation of common periwinkle (Littorina littorea (L.)) on a stony beach. J Anim Ecol 24:35-56

Underwood AJ (1973) Studies on zonation of intertidal prosobranch molluscs in the Plymouth region. J Anim Ecol 42:353372

Underwood AJ (1979) The ecology of intertidal gastropods. Adv Mar Biol 16:111-210

Vermeij GJ (1972) Intraspecific shore-level size gradients in intertidal molluscs. Ecology 53:693-699

Wahl M, Sönnichsen H (1992) Marine epibiosis IV. The periwinkle Littorina littorea lacks typical antifouling defences - why are some populations so little fouled? Mar Ecol Prog Ser $88: 225-235$

Wilhelmsen U (1998) Populationsgenetik und -ökologie von drei Littorina-Arten (Gastropoda) der Nord- und Ostsee. PhD thesis, University of Hamburg, Germany

Wilhelmsen U, Reise K (1994) Grazing on green algae by the periwinkle Littorina littorea in the Wadden Sea. Helgol Meeresunters 48:233-242

Williams E (1964) The growth and distribution of Littorina littorea (L.) on a rocky shore in Wales. J Anim Ecol 33:413-432

Williams GA (1995) Maintenance of zonation patterns in two species of flat periwinkle, Littorina obtusata and L. mariae. Hydrobiologia 309(1-3):143-150 